\title{
Energy cooperation between Russia and Mongolia: priority areas and mechanisms to pursue them
}

\author{
Boris Saneev ${ }^{1 *}$, Anatoly Korneev ${ }^{1}$, Sereeter Batmunkh² and Sodovin Bathuyag ${ }^{2}$ \\ ${ }^{1}$ Melentiev Energy Systems Institute of Siberian Branch of Russian Academy of Sciences, Irkutsk, Russia \\ ${ }^{2}$ Mongolian State University of Science and Technology, Ulan Bator, Mongolia
}

\begin{abstract}
The study examines the directions of Russian-Mongolian energy co-operation. The focus is on an analysis of internal and external factors that negatively affect the implementation of the current inter-country energy projects. The mechanisms are proposed to cope with the factors limiting energy cooperation.
\end{abstract}

\section{Introduction}

Interstate cooperation between Russia and Mongolia has a long history. During the Soviet period, it was characterized by close economic, energy, cultural, and many other ties. The transition to a market economy has significantly changed Mongolia's inter-country relations, which have become multi-vector ones. The country has intensified relations with China, with developed European countries, with the United States, and others. Although the cooperation between Russia and Mongolia has weakened over the past 25 years, it has not lost its importance, and, first of all, for the energy sector. Mongolia has rich mineral resources [1], and their development requires huge investments and a powerful energy supply system [2]. Mongolia has a long border with Russia, which has a developed fuel and energy resources and surplus energy power in the regions bordering Mongolia. Currently, Russia is rendering all possible assistance in providing reliable energy and fuel supply to Mongolian consumers, which can have a significant impact on the economic development of Mongolia and mutually beneficial cooperation between the two countries in the future.

The primary internal and external challenges and problems facing today's energy projects implemented in Russia and Mongolia with the NEA countries include [3, 4]:

- high investment, production, social and labor costs of the extraction, production, and transportation of energy products, which ultimately reduce their price competitiveness in the world energy market, including that in the neighboring countries of NEA;

- limited public investment in the development of infrastructure projects;

- high tariffs in electricity and heat supply for the production of energy products and their transportation (transmission) by various modes of transport, which significantly increase their domestic and export prices;

- poorly developed domestic innovation and technology base, which prevents a timely (synchronous with developed countries) transition to new efficient hightech production levels;
- increasing competition in the global energy market (dumping pricing policy, collusion for the imposition of financial, technological, and various economic sanctions, and others);

- unknown demand for energy resources due to the uncertainty of the world economy development and its structural transformations;

- restrictive measures related to the spread of coronavirus in the world and a downturn in business activity, and others.

Overcoming these unfavorable factors and increasing the possibilities for the implementation of inter-country energy projects require the flexible application of various mechanisms, both at the state and corporate levels.

The paper examines a wide range of mechanisms to be used, with the focus on the most important ones for specific areas and conditions of interstate energy cooperation between Russia and Mongolia.

\section{Priority areas of energy cooperation between Russia and Mongolia}

According to the state policy documents, the priority direction of the strategic development of the Mongolian energy sector is the improvement of its territorialproduction structure based on internal capabilities and mutually beneficial international energy cooperation with Russia and the NEA countries [4]. Russia's energy policy is also aimed at cooperation with the NEA countries. The Energy Strategy of the Russian Federation until 2035, adopted by the Government of the Russian Federation in 2020 , pays special attention to the energy development and the creation of a developed energy infrastructure in the eastern regions, which will increase the national energy security, strengthen fuel and energy ties between the countries and provide Russia's access to the energy markets of China, Japan, Mongolia and other countries of Northeast Asia and the Asia-Pacific region [3].

At present, the areas which are considered by the government, scientific, and business communities to be of

* Corresponding author: $\underline{\text { saneev@isem.irk.ru }}$ 
priority for the Russian-Mongolian energy cooperation include the following:

1. Supplying Russian natural gas to Mongolia. This goal can be achieved by constructing a gas pipeline to China through the territory of Mongolia. The PJSC Gazprom considers it possible to implement the new project of the Power of Siberia-2 gas pipeline with a capacity of 50 billion cubic meters of gas annually. Now it is being discussed at the intergovernmental level [5]. The implementation of this project will both provide large gas supplies to China, and increase the number of gas consumers along the route of the pipeline in the Irkutsk region, the Republic of Buryatia, the Trans-Baikal Territory, and Mongolia [6]. In this case, Mongolia will have to invest only in gas distribution pipeline networks, excluding the main gas pipeline and branches. At the same time, Mongolia's revenues from gas transit through its territory to China can be used for the development of gas distribution networks.

2. Providing Mongolian consumers with petroleum products. Two options are considered: the existing one, through an increase in the supply of petroleum products from Russia and the construction of the Darkhan refinery with a capacity of 2-3 million tons per year in Mongolia, and the supply of Russian oil by oil pipeline or railway transport.

3. Increasing direct supplies of electricity from Russia and building Asian Energy Super Ring in the distant future, which will interconnect the power systems of Russia, China, Japan, South Korea, and Mongolia. The second option suggests the construction and reconstruction of thermal power plants with a capacity of more than 6000 MW in Mongolia, and their connection to the interstate electric power system [7, 8].

4. Developing the world's largest Tavan Tolgoy deposit of coking coal with the participation of Russia and the supply of this coal to the NEA countries [9].

5. Constructing railways to transport large volumes of mined coal to external consumers and others, in the future. $[10,11]$.

The feasibility of the inter-country energy projects under consideration will, first of all, be determined by the rates of economic development of China and Mongolia, given the development of Mongolia's mineral resources, competitive (price) advantages of Russian energy resources, and the possibilities of overcoming some other internal and external limiting factors described above.

\section{Requirements for mechanisms to implement inter-country projects}

In the practice of promoting and supporting the projects planned for implementation, there are many organizational, economic, and legislative mechanisms $[12,13]$. In the context of energy cooperation with Mongolia, the most important of them include organizational and economic ones. Figure 1 presents an extended list of organizational measures designed for the countries to jointly develop coordinated proposals for energy cooperation projects, to work out interstate target programs for the economic development of individual territories and industries in conjunction with the implementation of inter-country energy projects, and others.

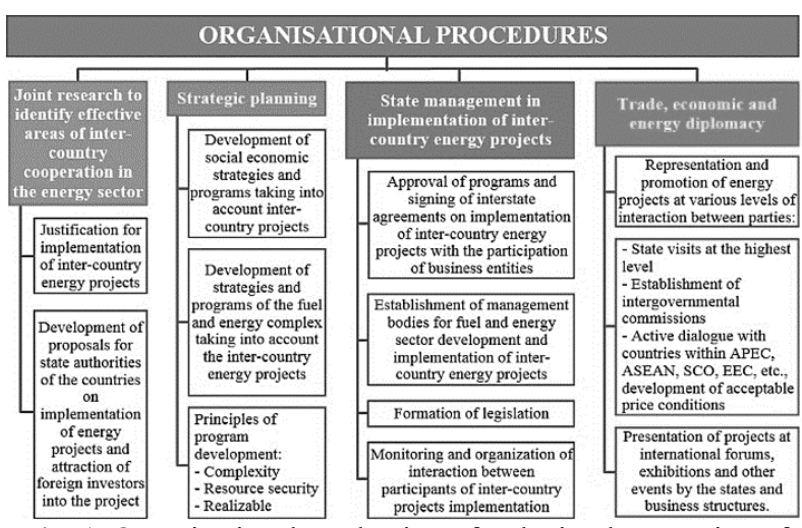

Fig. 1. Organizational mechanisms for the implementation of inter-country energy projects

In the stage of project implementation, an important role is played by the interstate government monitoring of the work progress and the timely elimination of obstacles by organizing coordinated actions of project participants, eliminating bottlenecks, and adjusting various project parameters.

The central point of substantiating the effectiveness of inter-country projects and their feasibility is the high competitiveness of energy products in terms of quality and price characteristics. Here economic mechanisms are of decisive importance. A list of them is shown in Figure 2.

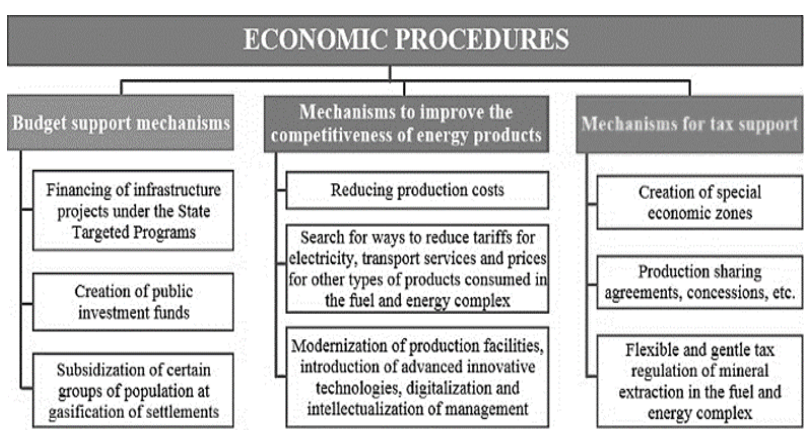

Fig. 2. The economic mechanisms to implement intercountry energy projects

At the present stage, the corporations should pay special attention to such economic mechanisms as the reduction in the costs of extraction, processing, production, and transportation of energy products based on the modernization of production facilities, the adoption of advanced innovative technologies, digitalization, and smartization of management. At the same time, the states should make maximum use of the mechanisms of budgetbased financial support for infrastructure projects within the framework of targeted state programs, and apply flexible and tax sparing regulation to the extraction of minerals in the energy sector.

Almost all economic mechanisms aimed at implementing inter-country projects are directly or indirectly related to the formation of sources and attraction of investments. The primary investment mechanisms are shown in Figure 3. 


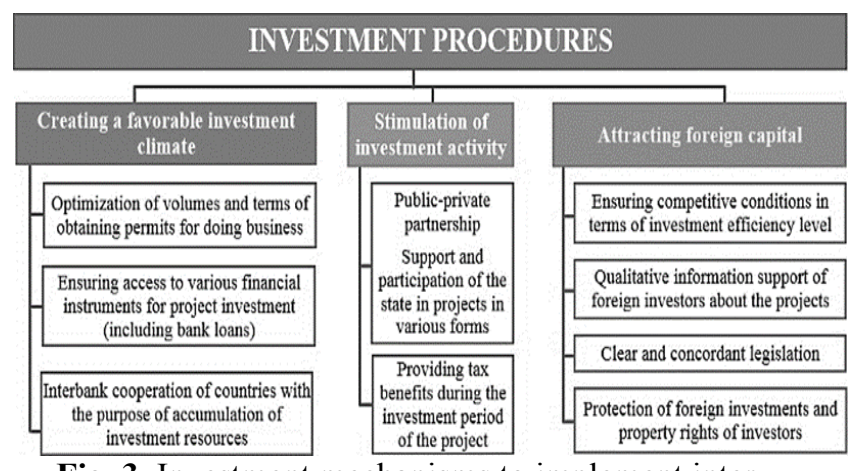

Fig. 3. Investment mechanisms to implement intercountry energy projects.

In the context of sanctions imposed by the Western countries on Russia and the restriction of access to credit resources of foreign banks, funding based on organizational and legislative mechanisms is becoming especially relevant:

- accessibility to various domestic financial tools for project investment, including bank loans, with interest rates not exceeding those of leading Western European banks;

- competitive conditions in terms of the efficiency of investment by domestic and foreign investors in the projects at issue compared to possible alternative projects;

- interbank cooperation of states implementing interstate energy projects to accumulate investment resources, and others.

Despite the existing experience in the implementation of inter-country projects for the supply of energy resources from the eastern regions of Russia to Japan, China, and other NEA countries, the existing mechanisms for the implementation of inter-country projects do not yet have a systemic (interconnected) nature of their use and require further improvement.

\section{Conclusion}

Energy cooperation between Russia and Mongolia, and the implementation of inter-country energy projects should be based on comprehensive program-targeted planning of economic development of the respective territories and leading industries of the parties involved, i.e. within the framework of programs agreed with investors and approved by governments. At present, the research teams of the Academies of Sciences of Russia and Mongolia systemically conduct studies to substantiate the directions of energy cooperation between the two countries for the time horizon until 2035. At the same time, they consider the Baikal region (Irkutsk region, the Republic of Buryatia, and the Trans-Baikal Territory) to be the base area for cooperation with Mongolia.

To ensure the competitiveness of export energy products produced within the framework of inter-country projects, corporations must focus on the most advanced technologies, have flexible, sparing taxation, acceptable tariffs for the energy supply within projects to be implemented and the transportation of energy products, which in general significantly reduces costs and increases the flexibility of export prices.
Another crucial factor in reducing investor costs and increasing the efficiency of inter-country energy projects is active, multilateral, and systematic state infrastructure support for the projects.

The study was carried out within the framework of an international grant from the Russian Foundation for Basic Research (project No. 18-510-94006) and the Ministry of the Education, Culture, Science, and Sport of Mongolia (project No. $\mathrm{Shu} / \mathrm{Gh} / \mathrm{OHU} / 2018 / 26) /$

\section{References}

1. Minerals of Mongolia. Available at: http://mongol.su/wiki/index.php/ (Accessed: 07.07.2020)

2. Program for Mongolia's Integrated Power Supply System. Available at: https://docplayer.ru/44312082Mongoliya-politika-energeticheskogo-razvitiya-iinvesticionnyh-vozmozhnostey (accessed: 08/01/2020)

3. Energy strategy of the Russian Federation until 2035. Available at: https://minenergo.gov.ru/node/18038 (accessed: 15.08.2020).

4. State energy policy for 2015-2030, approved by the Decree of the State Great Khural No. 63, of June 19, 2015. Ulan Bator (2015)

5. Gazprom and Mongolia will set up a joint venture for the construction of a gas pipeline to China. Available at:

https://www.vedomosti.ru/business/articles/2020/08/ 25/837742-gazprom-mongoliya (accessed: 10.07.2020)

6. Saneev B.G., Popov S.P., Maksakova D.V. A switch to gas in Mongolia: Opportunities for Multilateral Cooperation. Energy Policy, No. 3 (145), pp. 34-46 (2020)

7. Borisov G.O., Zdarov R.A. Interaction of Mongolia and Russia's energy systems within the economic corridor/ed. by V.G. Belomestnov. Proceedings of the VI International Science and Practice Conference "Social and Economic Development of Russia and Mongolia: Problems and Prospects". Ulan-Ude, VSGUTU Publ. House, p. 50-55 (2019)

8. Stennikov V.A., Batmunkh S., Saneev B.G. Strategic directions for the development of the electric power industry in Mongolia. Proceedings of RAS. Power Engineering, No. 6, p. 51-65 (2019)

9. P. Ochirbat. Coal industry of Mongolia: state and development prospects. Notes of the Mining Institute, v. 226, p. 420-427 (2017)

10. Minutes of the 22nd meeting of the Intergovernmental Russian-Mongolian Commission on Trade, Economic, Scientific and Technical Cooperation of May 30, Ulan Bator, 22 p. (2019)

11. Voropai N.I., Saneev B.G., Batkhuyag S., Enkhzhargal H. Energy cooperation between Mongolia and Russia: current state and strategic directions. Spatial Economics, No. 3, p. 108-122 (2013)

12. The Asian part of Russia: modeling of economic development in the context of the experience of 
history. / Ed. by V.A. Lamin, V.Yu. Malov. Novosibirsk: Publ. House of the SB RAS, p. 343-356 (2012)

13. Fuel and energy complex of the Baikal region: current state, development prospects/ed. by B.G. Saneev; Russian Academy of Sciences, Siberian Branch, Melentiev Energy Systems Institute. Novosibirsk: Academic publishing house "Geo", p.162-168 (2015) 